\title{
GENDER-SPECIFIC DIFFERENCES OF CARDIAC VEGETATIVE CONTROL IN ADRENALINE-INDUCED NECROSIS AND LIGHT DEPRIVATION
}

\author{
H.O. Bezkorovaina, I.M. Klishch, *M.R. Khara, V.Ye. Pelykh \\ I. HORBACHEVSKY TERNOPIL NATIONAL MEDICAL UNIVERSITY, TERNOPIL, UKRAINE
}

Background. Cardiovascular disease is the main cause of morbidity predominantly in males. Stress is one of the crucial factors, especially with light desynchronosis.

Objective of the study was to assess gender-specific characteristics of cardiac vegetative control in myocardial necrosis in cases of light deprivation.

Methods. Cardiac vegetative control in adrenaline-induced myocardial necrosis (AIMN) in a setting of light deprivation (LD) was assessed in 72 mature white rats of both sexes. The animals were divided into 2 groups: G1 - the animals kept under day/night cyclic balance (12 hours/12 hours); G2 - the animals kept at LD (illumination 0.5-1 LX) for 10 days. On Day 11, AIMN caused by adrenaline (0.5 mg/kg) and heart rate variability (HRV) was assessed in 1 hour and 24 hours.

Results. The development of AIMN at LD in the o G2 led to HRV increase that was caused by augmentation of parasympathetic and reduction of sympathetic cardiac effects. In cases of AIMN, changes of CVC in the + G2 were similar to the $+G 1$. However, in 1 hour of AIMN, parasympathetic cardiac effects were more significant than in the o G1. While the o G2 AIMN animals experienced balanced sympathetic and parasympathetic actions, the predominance of the sympathetic component was evidenced in the o G1 AIMN animals.

Conclusions. Light deprivation has different effects on baseline sympathetic/parasympathetic balance in males and females, i.e. increased parasympathetic control of heart rhythm in males and maintenance of sympathetic/ parasympathetic balance in females.

KEY WORDS: myocardial necrosis; heart rhythm variability; light deprivation; gender.

\section{Introduction}

According to the WHO data, cardiovascular disease is the most frequent cause of death in the European population; moreover, it has frequent severe sequelae, leads to disability and reduces the quality of life. Ukraine is on the list of countries in Eastern Europe, where coronary artery disease (CAD) mortality in people of 55-60 years of age is higher than that in French subjects 20 years senior [1]. The leading causes of increased mortality include ageing population and lifestyle factors, especially smoking and suffering from overweight [2]. Males are more frequently affected by coronary artery disease than females. This difference, however, is found in the middleaged persons. At menopause, the number of females in the population with coronary episodes and myocardial infarction increases greatly. This might be associated with deficiency of oestrogens and their diminished cardioprotective and vasoprotective activity [3].

*Corresponding author: Khara Mariya, MD, Ph.D., DSc, Professor of the Department of Pathophysiology, I. Horbachevsky Ternopil National Medical University, Ternopil, Ukraine. E-mail: khara@tdmu.edu.ua
Important risk factors of myocardial necrosis include impaired circadian rhythms and functional disorders of the pineal gland $[4,5]$. This is related to professional activity, sleep disorders and difficulty falling asleep $[6,7]$. Similar to all other systems in the body, the cardiovascular system is controlled by the pineal gland. Its activity changes depending on the phase of the circadian cycle (light/darkness), as suggested by fluctuations in blood pressure and heart rhythm variability $[5,8]$. However, the effects of melatonin synthesised by the pineal gland vary in males and females that is associated not only with the ability of this hormone to regulate the synthesis of sex hormones [4, $9,10]$, but also to its capability to change the activity of sympathetic and parasympathetic components of the autonomic nervous system (ANS) $[11,12]$. Murine experiments have demonstrated different ANS responses to melatonin in males and females [11]. A higher basal tone of the parasympathetic component in female ANS contributes to a better cardioprotective effect of melatonin when adrenalineinduced myocardial necrosis is modelled in a 
setting of melatonin [13]. A similar trend was found in humans. Analysis of ANS status (as reported by a 24-hour monitoring of heart rhythm variability) suggests reduced parasympathetic tone and increased sympathetic activity as predictors of fatal arrhythmias and sudden death in subjects with myocardial infarction [14]. The benefits of heart rhythm variability analysis and its diagnostic and prognostic value are beyond doubt. The use of this method allows assessment of cardiac vegetative control in a study of pathogenetic role of light desynchronosis as a contributor to myocardial necrosis. However, the available data do not provide a full understanding of the role of ANS in adaptation of heterosexual organisms to abnormal light conditions, including the development of cardiac disease under these conditions.

The objective of the study was to assess gender-specific characteristics of cardiac vegetative control in adrenaline-induced myocardial necrosis in rats in cases of light deprivation.

\section{Methods}

The experiments were conducted according to ethical guidelines approved by the European Convention for the Protection of Vertebrate Animals Used for Experimental and Other Scientific Purposes (Strasbourg, 1986), resolution of the First National Congress on Bioethics (Kyiv, 2001) and the Order of the Ministry of Health of Ukraine No. 690, dated September 23,2009 . The tests were performed on 72 nonlinear male and female white rats (body weight: 220-270 g; age: 5-5.5 months). The rats were provided with a standard laboratory pellet diet and water and were housed in plastic cages at constant ambient temperature and humidity. The rats of the control group (group 1, $180^{7}$, 18 \% ) were kept under a natural day/night cycle (light 12 hours, 500 LX/night 12 hours, 0.5-1 LX). The rats of the experimental group (group 2, $180^{x}, 18$ o ) were kept in permanent darkness (0.5-1 LX) for 10 days. Necrosis of myocardium was modelled by administration of adrenaline (intramuscular, $0.5 \mathrm{mg} / \mathrm{kg}$ of body weight) on day 11 . In 1 and 24 hours after adrenaline administration, EKG was captured (2 standard leads) using a Cardiolab-CE computer-based complex (Kharkiv, Ukraine). The durations of 1000 consecutive cardiac R-R intervals accurate to 0.001 second were assessed. In order to evaluate the regulatory activity of sympathetic and parasympathetic ANS components on the heart rhythm, the following parameters were registereg: $\mathrm{Mo}(\mathrm{sec})=$ mode, i.e. the most frequently captured duration of the R-R interval; AMo $(\%)=$ the amplitude of mode, i.e. the percentage of cardiac intervals meeting the Mo value; $\Delta \mathrm{X}(\mathrm{sec})=$ the difference between the largest and the smallest R-R value; HSI (abs. value) $=$ heart strain index reflecting the degree of centralisation of heart rhythm control, this parameter is obtained from the following expression: $\mathrm{HSI}=\mathrm{AMo} /(2 \cdot \Delta \mathrm{X} \cdot \mathrm{Mo})$; VBI (abs. value) $=$ vegetative balance index reflecting the ratio between the activities of the sympathetic and parasympathetic nervous system, this parameter is obtained from the following expression: $\mathrm{VBI}=\mathrm{AMo} / \Delta \mathrm{X}$; VRI (abs. value) = vegetative rhythm index reflecting the activity of the autonomic circuit of heart rhythm control, this parameter is obtained from the following expression: VRI $=1 / \mathrm{Mo} \cdot \Delta \mathrm{X}$, and IARP (abs. value) $=$ index of adequate regulation processes reflecting the balance between the activity of the sympathetic component of the autonomic nervous system and the predominant functional level of the sinus node. By matching against heart rhythm (HR), this parameter allows judgment on excessive or insufficient centralisation of heart rhythm control; this parameter is obtained from the following expression: IARP=AMo/Mo.

Statistical analysis of the results was performed using parametric method of variation statistics based on established normal distribution of data in the rows compared, with $n=6$ in each of the rows. The following parameters were determined by the arithmetic mean (M), standard deviation ( $\overline{0})$ and Student's $\mathrm{t}$-test $(\mathrm{t})$. The difference between the arithmetic means was statistically significant at $t$ value not less than 2.228 ( $p \leq 0.05)$. Microsoft Excel XP (BioStat Pro 6.7.1.0) software (US) was used for calculations.

\section{Results}

The results attained in the animals of the control group (Group 1), which were under conditions of balanced light/darkness (12 hours/12 hours), are presented in Table 1.

The development of adrenaline-induced myocardial necrosis within 1 hour after adrenaline administration was found to cause a significant increase in HR (by $12.5 \%$ in the $0^{*}$, by $13 \%$ in the,$+ p<0.05)$. This process was accompanied by a predictable reduction in Mo values (by $12 \%$ in the $o^{x}$, by $13 \%$ in the o ). AMo values were increased in the ${ }^{*}$ (by $87 \%, p<0.05$ ) and the $q$ animals by $(34 \%, p<0.05)$. The $\Delta \mathrm{X}$ 
Table 1. Parameters of heart rhythm variability in the rats developing adrenaline-induced myocardial necrosis under the intact day/night cycle (12 hours/12 hours), $M \pm \overline{0}$

\begin{tabular}{|c|c|c|c|c|}
\hline Parameter & Gender & $\begin{array}{l}\text { Controls } \\
(n=6)\end{array}$ & $\begin{array}{c}1 \text { h post-adrenaline } \\
(\mathrm{n}=6)\end{array}$ & $\begin{array}{l}24 \text { h post-adrenaline } \\
(n=6)\end{array}$ \\
\hline \multirow[t]{2}{*}{ HR } & $0^{x}$ & $472 \pm 21 \#$ & $531 \pm 17 *$ & $491 \pm 29$ \\
\hline & 우 & $438 \pm 19 \#$ & $496 \pm 27 *$ & $481 \pm 12 *$ \\
\hline \multirow[t]{2}{*}{ Mo (sec) } & $0^{x}$ & $0.127 \pm 0.006 \#$ & $0.113 \pm 0.002 * \#$ & $0.122 \pm 0.007$ \\
\hline & 우 & $0.137 \pm 0.006 \#$ & $0.121 \pm 0.007 * \#$ & $0.125 \pm 0.003 *$ \\
\hline \multirow[t]{2}{*}{ AMo (\%) } & $0^{x}$ & $31.7 \pm 3.8$ & $59.2 \pm 5.8 \#$ & $43.7 \pm 7.5^{*}$ \\
\hline & q & $33.8 \pm 4.5$ & $45.2 \pm 5.0$ *\# & $41.2 \pm 3.1$ * \\
\hline \multirow[t]{2}{*}{$\Delta \mathrm{X}\left(\mathrm{sec} \cdot 10^{-2}\right)$} & $0^{x}$ & $0.65 \pm 0.22$ & $0.35 \pm 0.08 *$ & $0.58 \pm 0.04 \#$ \\
\hline & q & $0.55 \pm 0.14$ & $0.33 \pm 0.05 *$ & $0.40 \pm 0.06 * \#$ \\
\hline \multirow[t]{2}{*}{ HSI (abs. value) } & $0^{x}$ & $21621 \pm 9813$ & $79493 \pm 23420 *$ & $30953 \pm 6342 \#$ \\
\hline & ㅇ & $23875 \pm 7223$ & $57384 \pm 10855 *$ & $42514 \pm 9872 * \#$ \\
\hline \multirow[t]{2}{*}{ VBI (abs. value) } & $0^{x}$ & $5425 \pm 2245$ & $17873 \pm 4936 *$ & $7527 \pm 1391 \#$ \\
\hline & 우 & $6578 \pm 2211$ & $13783 \pm 2142 *$ & $10598 \pm 2484 * \#$ \\
\hline \multirow[t]{2}{*}{ VRI (abs. value) } & $0^{x}$ & $1333 \pm 470$ & $2716 \pm 935 *$ & $1418 \pm 190 \#$ \\
\hline & 우 & $1419 \pm 442$ & $2537 \pm 419 *$ & $2051 \pm 347 * \#$ \\
\hline \multirow[t]{2}{*}{ IARP (abs. value) } & $0^{x}$ & $0.250 \pm 0.040$ & $0.525 \pm 0.058 * \#$ & $0.358 \pm 0.061 *$ \\
\hline & 운 & $0.247 \pm 0.038$ & $0.375 \pm 0.056 * \#$ & $0.330 \pm 0.024 *$ \\
\hline
\end{tabular}

Note: * a statistically significant $(p \leq 0.05)$ differences relative to the controls, \# - relative to the animals of the opposite sex.

values significantly decreased in the animals of either sex (by $97 \%$ in the $\sigma^{x}$, by $67 \%$ in the + , $\mathrm{p}<0.05)$. HSI, which is an integral parameter, increased in the animals of either sex (a 3.7-fold increase in the $0^{x}$, a 2.4-fold increase in the + , $\mathrm{p}<0.05)$. Such changes reflected the increased role of the sympathetic ANS component and the reduced influence of the parasympathetic component in heart rhythm control. These findings were confirmed by increases in VBI (a 3.3-fold increase in the $0^{*}$, a 2.1-fold increase in the,$+ p<0.05$ ), VRI (a 2.0-fold increase in the $\sigma^{x}$, a 1.8-fold increase in the $\left.o, p<0.05\right)$ and IARP (a 2.1-fold increase in the $0^{x}$, a 1.5-fold increase in the o,$p<0.05)$.

In 24 hours after adrenaline administration (i.e. the peak of focal necrosis), the type of ANS response to development of the abnormal process changed somewhat. In the $o^{x}$ animals, the findings of $H R, M o, \triangle X, V B I$ and VRI recovered to the control levels, AMo decreased (by $35 \%, p<0.05$ ), while IARP were above control values (by $43 \%, p<0.05$ ). In the of rats, HR was higher (by 10\%, $\mathrm{p}<0.05$ ) and Mo was lower (by $10 \%, p<0.05$ ). The following parameters were higher than the respective control values: AMo (by $38 \%, p<0.05$ ), HSI (by $78 \%, p<0.05$ ), VBI (by $61 \%, p<0.05$ ), VRI (by $45 \%, p<0.05$ ) and IARP (by $34 \%, p<0.05)$.

Gender-specific analysis showed Mo in the Group 1 lower in the $0^{x}$ than in the + (by $8 \%$, $\mathrm{p}<0.05)$. In 1 hour of necrotic process development, Mo was lower than in the $+(7 \%, p<0.05)$, AMo was higher (by $31 \%, p<0.05$ ) and IARP was also higher (by $40 \%, p<0.05$ ). In 24 hours after adrenaline administration, the $\Delta \mathrm{X}$ in the $\sigma^{*}$ was higher than in the + (by $45 \%, \mathrm{p}<0.05$ ) and HSI, VBI and VRI were lower (by $37 \%, 41 \%$ and $45 \%$, $p<0.05$, respectively), reflecting gender-specific differences of cardiac adjustment mechanisms in cases of ANS-mediated damage.

Analysis of parameters in the animals of the experimental group (Group 2) that were kept in permanent darkness for 10 days (light deprivation) showed that in 1 hour of myocardial necrosis development, $o^{x}$ animals had lower HR (by $9 \%, p<0.05)$, higher Mo (by $9 \%, p<0.05)$ and lower $\Delta X$ (by $23 \%, p<0.05$ ) (Table 2). As for other parameters, no significant changes were evidenced. When the $q$ animals were exposed to identical conditions, HR increased (by $6 \%$, $\mathrm{p}<0.05$ ), while Mo and $\Delta \mathrm{X}$ decreased (by $6 \%$ and $29 \%$, respectively, $p<0.05)$. Under these conditions, the increase in HSI, VBI and VBI were quite predictable (by $65 \%, 55 \%$ and $40 \%$, respectively, $p<0.05)$. IARP values did not change.

In 24 hours after adrenaline administration, the $\sigma^{x} \mathrm{HR}$ was lower than in the controls (by $16 \%$, $p<0.05$ ), Mo was higher (by $16 \%, p<0.05$ ) and IARP was lower (by $34 \%, p<0.05$ ). In the of at this phase of myocardial necrosis, HR was higher (by $6 \%, p<0.05$ ), Mo was lower (by $6 \%$, 
Table 2. Parameters of heart rhythm variability in the rats with developing adrenaline-induced myocardial necrosis in cases of light deprivation, $(\mathrm{M} \pm \overline{0})$

\begin{tabular}{|c|c|c|c|c|}
\hline Parameter & Gender & $\begin{array}{l}\text { Controls } \\
(n=6)\end{array}$ & $\begin{array}{l}1 \text { hours post-adrenaline } \\
(\mathrm{n}=6)\end{array}$ & $\begin{array}{l}24 \text { hours post-adrenaline } \\
(\mathrm{n}=6)\end{array}$ \\
\hline \multirow[t]{2}{*}{ HR } & $0^{x}$ & $512 \pm 14^{\wedge} \#$ & $469 \pm 21 * \wedge$ & $443 \pm 29 * \wedge$ \\
\hline & 우 & $435 \pm 11 \#$ & $463 \pm 11 * \wedge$ & $461 \pm 22 *$ \\
\hline \multirow[t]{2}{*}{ Mo (sec) } & $\sigma^{x}$ & $0.117 \pm 0.003^{\wedge} \#$ & $0.128 \pm 0.006 * \wedge$ & $0.136 \pm 0.009 * \wedge$ \\
\hline & 우 & $0.138 \pm 0.003 \#$ & $0.130 \pm 0.003 * \wedge$ & $0.130 \pm 0.006 *$ \\
\hline \multirow[t]{2}{*}{ AMo (\%) } & $\sigma^{x}$ & $38.3 \pm 7.8^{\wedge}$ & $34.3 \pm 3.7^{\wedge}$ & $33.0 \pm 2.7^{\wedge}$ \\
\hline & 우 & $32.7 \pm 4.4$ & $38.3 \pm 5.2$ & $40.5 \pm 11.6$ \\
\hline \multirow[t]{2}{*}{$\Delta \mathrm{X}\left(\mathrm{sec} \cdot 10^{-2}\right)$} & $\sigma^{x}$ & $0.70 \pm 0.13$ & $0.57 \pm 0.08 * \wedge \#$ & $0.75 \pm 0.08^{\wedge} \#$ \\
\hline & 우 & $0.58 \pm 0.04$ & $0.45 \pm 0.08 * \wedge \#$ & $0.50 \pm 0.14 \#$ \\
\hline \multirow[t]{2}{*}{ HSI (abs. value) } & $\sigma^{x}$ & $24730 \pm 9622$ & $24464 \pm 6557^{\wedge} \#$ & $16398 \pm 2345^{\wedge} \#$ \\
\hline & 우 & $20535 \pm 3552$ & $33835 \pm 7738 * \wedge \#$ & $34836 \pm 17417 * \#$ \\
\hline \multirow[t]{2}{*}{ VBI (abs. value) } & $\sigma^{x}$ & $5672 \pm 2123$ & $6223 \pm 1446^{\wedge} \#$ & $4458 \pm 846^{\wedge} \#$ \\
\hline & 우 & $5642 \pm 939$ & $8732 \pm 1891$ *^\# & $9118 \pm 4656 * \#$ \\
\hline \multirow[t]{2}{*}{ VRI (abs. value) } & $\sigma^{x}$ & $1257 \pm 234$ & $1405 \pm 244^{\wedge}$ & $996 \pm 118^{\wedge} \#$ \\
\hline & 우 & $1256 \pm 90$ & $1762 \pm 299 * \wedge$ & $1657 \pm 517 \#$ \\
\hline \multirow[t]{2}{*}{ IARP (abs. value) } & $\sigma^{x}$ & $0.326 \pm 0.060 \#$ & $0.268 \pm 0.039^{\wedge} \#$ & $0.243 \pm 0.010 * \wedge$ \\
\hline & 우 & $0.238 \pm 0.036 \#$ & $0.296 \pm 0.043 \#$ & $0.309 \pm 0.078$ \\
\hline
\end{tabular}

Note: * - statistically significant $(p \leq 0.05)$ differences relative to the controls, $\wedge$ - relative to the findings in the group 1 animals during the same observation period, \# - relative to the animals of the opposite sex.

$p<0.05$ ), HSI and VBI were higher (by $70 \%, 62 \%$, $\mathrm{p}<0.05)$, and AMo, $\Delta \mathrm{X}, \mathrm{VRI}$ and IARP did not differ from the respective baseline values in this group.

Gender-specific analysis showed that HR and IARP in the control group was higher in the $\sigma^{\pi}$ than in the of (by $18 \%, 37 \%, p<0.05$ ); the Mo values were lower (by $18 \%, \mathrm{p}<0.05)$. There were no differences between the animals in terms of other parameters. In 1 hour of myocardial necrosis, $\Delta \mathrm{X}$ in the $0^{x}$ was higher than in the of (by $27 \%, \mathrm{p}<0.05$ ); HSI, VBI and IARP were lower (by $38 \%, 40 \%$ and $10 \%, p<0.05$ ). In 24 hours of myocardial necrosis, $\Delta \mathrm{X} \mathrm{o}^{\mathrm{T}}$ was significantly higher (by $50 \%, \mathrm{p}<0.05$ ), and HSI, VBI and VRI were lower (in 2.1 times, 2.0 times and 1.7-times, respectively, $\mathrm{p}<0.05)$.

In terms of ANS responses, effects of light deprivation in development of myocardial necrosis have shown that staying in darkness for 10 days had different influences on vegetative control of heart rhythm in male and female animals. In $\sigma^{x}, H R$ increased by $8.5 \%(p<0.05)$, Mo decreased by $85 \%(p<0.05)$. Other parameters remained unchanged and were not statistically different from those in animals of Group 1. In the of cohort, light deprivation did not cause any changes in investigational parameters.

Under conditions of a necrotic process ( 1 and 24 hours after administration of adrenaline), $\mathrm{HR} \mathrm{O}^{\pi}$ was lower than the respective values in
Group 1 ( $13 \%$ and $11 \%$, respectively, $\mathrm{p}<0.05)$; in the meantime, Mo was higher $(13 \%$ and $11 \%$, respectively, $p<0.05)$, AMo was lower $(73 \%$ and $32 \%$, respectively, $\mathrm{p}<0.05)$ and $\Delta \mathrm{X}$ was higher ( $63 \%$ and $29 \%$, respectively $p<0.05$ ). All integral parameters were significantly lower than comparative ones; in part, this was true of HSI (in 3.3 times and 1.9 times, $p<0.05$ ), VBI (in 2.9 times and 1.7 times, $p<0.05$ ), VRI (in 1.9times and 1.4times, $p<0.05$ ) and IARP (in 2.0 times and 1.5 times, $p<0.05)$. The differences between Group 1 and Group 2 in the females in 1 hour after adrenaline administration were for $\mathrm{HR}$ (by $7 \%$ lower, $p<0.05$ ), Mo (by 7\% higher, $p<0.05$ ) and $\Delta X(36 \%$ higher, $p<0.05)$; the values of HSI, VBI and VRI were lower (in1.7 times, 1.6 times and 1.4 times, respectively, $p<0.05$ ). In 24 hours after adrenaline administration, no significant differences were evidenced regarding the parameters.

\section{Discussion}

Analysis of heart rhythm variability is performed by a non-invasive method of functional diagnostics, which is used not only in a clinical setting, but also in experimental studies. It allows assessing of cardioregulatory ANS activity, determining the balance between activities of sympathetic and parasympathetic components as they affect the heart rhythm, making a conclusion about the predominant 
component, and assessing the stress upon regulatory systems as part of adjustment to adverse influences [15]. Analysis of histograms reflecting the distribution of RR intervals (variational pulsography) was used in the study. Assessment of the results involved use of a cybernetic double-circuit model for heart rhythm regulation as suggested by R.M. Bayevsky: the central circuit (cerebral cortex, higher autonomic centres and the cardiovascular centre) and the autonomic circuit (sinus node, lungs and the respiratory centre) [16]. The patterns of changes in experimental findings with time allowed drawing a conclusion that significant difference in ANS effects on the heart rhythm occurred between male and female animals. In males, development of adrenaline-induced myocardial necrosis under normal day/night balance was accompanied by an increased impact of sympathetic ANS component, as evidenced by increased levels of HSI, VBI, VRI and IARP. A more significant increase in test parameters in 1 hour of the experiment was predictable due to a presence of hypercatecholaminemia caused by administration of adrenaline. The effects of adrenaline were not limited to the sinus node, but also extended to myocardial contractility. This was also true regarding its metabolite, adrenochrome [17]. The amount of adrenochrome increased significantly under our experiment as a result of catabolism and an active part of myocardial damage through stimulation of free radical processes [18]. Under the circumstances, ANS response to hypercatecholaminemia-induced oxidative stress was also a matter of discussion. This was confirmed by ipsidirectional but less significant changes in ANS responses in the females. In this model, the severity of myocardial damage was substantially lower in the females [19]. In this case, the increase in AMo reflected strengthening of the central circuit of heart rhythm regulation, and the decrease in $\Delta \mathrm{X}$ reflected the reduced involvement of the autonomic circuit, i.e. the role of the vagus nerve. This data is consistent with the literature on using a model with adrenaline-induced myocardial necrosis. It was established that not only hypercatecholaminemia, but also sex hormones were crucial in the capacity of ANS to develop other adaptive effects [20, 21]. In 24 hours after adrenaline administration, the primary effects of adrenaline diminished according to the pattern described. In the males, all of the parameters were normal again, which was proved by a recovery of the baseline balance between ANS components. In the females, all pulsographic parameters demonstrated retention of increased sympathetic activity, which was the principal difference between the males and females.

The males of Group 2 responded to a 10-day stay in darkness with increased HR and with an accordingly reduced Mo. This reflected the state of stress and the increased involvement of humoral adaptive mechanisms, which were implemented by the adrenal glands [22]. The maintenance of regulatory balance under such conditions was attained at the expense of reduced activity of the central regulatory circuit, as confirmed by a reduction in AMo. Therefore, adjustment of the males in Group 2 to permanent darkness caused a moderate activation of sympathetic cardiac effects. In such a situation, myocardial necrosis developed under activation of the parasympathetic component and predominance of the latter in heart rhythm control. This was confirmed by higher (compare to the Group 1 animals) $\Delta \mathrm{X}$ values and by lower values of HSI, VRI, VBI and IARP. Lower AMo values have demonstrated that the predominance of parasympathetic ANS component was also facilitated by the reduced activity of sympathetic ANS component.

A 10-day stay of the Group 2 females under conditions of permanent darkness did not cause any functional changes in the ANS, as confirmed by the absence of significant differences in all parameters in the Group 1 and Group 2 females. In 1 hour after administration of adrenaline, HR increased and Mo decreased in the females of Group 2, which reflected an increase in adrenergic effects of ANS in the heart, with the effects implemented through the humoral channel (mainly the adrenal glands). The reduction in $\Delta \mathrm{X}$ suggested a decrease in vagal cardiac effects. As a natural result, HSI, VBI and VRI values increased. The constancy of IARP reflected a preserved balance between the central and the autonomic circuits of heart rhythm control. In 24 hours after adrenaline administration, HR was still increased, and Mo was lower than in the controls of this group. To a greater degree than in the controls, the HSI and VBI values demonstrated a predominance of sympathetic ANS effects in heart rhythm control, but the stability of IARP suggested a preserved balance between the activities of the central and the autonomic control circuits. It is important that under developing myocardial necrosis, the changes of parameters with time were similar to those 
in the Group 1, although less significant. In particular, Mo was higher in the Group 2 females compare to those of Group 1, which suggested a less active involvement of adrenal glands under the simulated conditions [22]. In this case, there was no involvement of the central control circuit, as confirmed by the absence of significant AMo changes. This demonstrated a lack of response of cerebral cortex to hyperadrenalinemia. Despite the increases in HSI, VBI and VRI values in 1 hour of myocardial necrosis (which reflected a phase of hyperadrenalinemia), these values were significantly lower than in the Group 1 females. To a degree greater than in the Group 1 animals, the $\Delta \mathrm{X}$ value reflected a more active involvement of parasympathetic mechanisms in cardiac adjustment to damage, which maintained a stable IARP and preserved a baseline balance between central and autonomic control circuits, unlike the Group 1 females, where the control balance shifted towards predominance of sympathetic ANS activity.

The development of necrotic process in the myocardium of the Group 2 males was accompanied by activation of cholinergic mechanisms of cardiac control, which was more significant than in the females. This proved that the males and females employed different mechanisms of adjustment to adverse effects of adrenaline under light deprivation. These differences may be associated with different levels of melatonin synthesis by the pineal gland under conditions of permanent darkness $[9,23]$. The females synthesises more melatonin at night-time [10] and their melatonin synthesis during sleep peaked sooner than in the males [24]. Considering that all animals in the experiment were under identical conditions, higher melatonin levels in the females could be asserted. However, a clearer understanding of the significance of endogenous melatonin within a framework of adaptive responses with ANS involvement in modelling of adrenaline-induced myocardial necrosis might yield the results attained in modelling of cardiac disease under permanent lighting, which was the prospect of the research. In summary, it should be noted that the attained data have proved that the males and females have different ANS responses to developing adrenaline-induced myocardial necrosis under light deprivation that suggests the necessity to specify the gender of animals in the conclusions and the incorrectness of extrapolating the established patterns to animals of other sex.

\section{Conclusions}

A 10-day light deprivation activates the heart rhythm impact of the sympathetic component of ANS in the male rats and does not alter the baseline balance of sympathetic and parasympathetic components of ANS in the females. The development of adrenalineinduced myocardial necrosis under 10-day light deprivation is characterised by a higher (compared today/night cycle) involvement of the parasympathetic ANS component in heart rhythm control in the males and by development of bradycardia. In the females, light deprivation facilitates the maintenance of sympathetic/ parasympathetic balance in cases of adrenalineinduced myocardial necrosis. This differs from the females under the day-night cycle, where an increase in the sympathetic component of the ANS was evidenced in cases of developing myocardial necrosis.

\section{Funding}

This research received no external funding. Conflict of Interests

The authors declare no conflict of interest.

\section{Authors Contributions}

Bezkorovaina H.O. - conceptualization, formal analysis, investigation, methodology, visualization, writing - original draft; Klishch I.M. conceptualization, supervision, resources; Khara M.R. - formal analysis, investigation, methodology; Pelykh V.Ye. - investigation.

\title{
СТАТЕВА ВІДМІННІСТЬ ВЕГЕТАТИВНОЇ РЕГУЛЯЦІї СЕРЦЯ ЩУРІВ ПРИ АДРЕНАЛІН-ІНДУКОВАНОМУ НЕКРОЗІ НА ТЛІ СВІТЛОВОЇ ДЕПРИВАЦІЇ
}

\author{
Г.О. Безкоровайна, І.М. Кліщ, М.Р. Хара, В.Є. Пелих \\ ТЕРНОПІЛЬСЬКИЙ НАЦІОНАЛЬНИЙ МЕДИЧНИЙ УНІВЕРСИТЕТ IМЕНІ І.Я. ГОРБАЧЕВСЬКОГО, \\ ТЕРНОПІЛЬ, УКРАЇНА
}


Мета дослідження. Вивчити гендерні особливості вегетативної регуляції серця при адреналініндукованому некрозі міокарда в щурів на тлі світлової деривації.

Методи дослідження. У 72 білих статевозрілих самців і самиць шурів досліджували варіабельність серцевого ритму (ВСР) при адреналін-індукованому некрозі міокарда (АНМ) на тлі світлової депривації (СД). Тварин поділили на 2 групи: Г1 - тварини були в умовах циклу день/ніч (12 год/12 год); та Г2 - щури перебували 10 днів в умовах світлової депривачії (СД). На 11-й день моделювали АНМ (адреналін в/м, 0.5 мг/кг) і ВСР вивчали через 1 ma 24 год.

Результати. Розвиток АНМу о Г1 $і$ і $Г 1$ викликав зменшення варіабельності серцевого ритму (BCP), посилення симпатичних впливів на серце, що було суттєвішим в $0^{x}$. СД викликала посилення симпатичних впливів на серце в о Г2. Розвиток АНМ в о Г2 викликав суттєве збільшення ВСР та значне зменшення ЧСС. Це було результатом посилення парасимпатичних впливів на серце та зменшення симпатичних. у ч Г2 в умовах АНМ динаміка показників ВСР була аналогічною до такої в о Г1. Проте, на 1 год АНM активність парасимпатичних впливів на серце була більшою, ніж в ю Г1. Якщо в ю Г2 в умовах АНМ зберігався баланс між активністю симпатичної та парасимпатичної ланок, то в о Г1 в умовах АНМ переважала активність симпатичної ланки.

Висновки. Світлова депривація посилює симпатичні впливи на ритм серця в самців щурів $і$ не змінює вихідного балансу активності симпатичної та парасимпатичної ланок в самиць. Розвиток адреналін-індукованого некрозу міокарда на тлі світлової депривації характеризується більшою, ніж за збереженого балансу день/ніч, активністю парасимпатичної ланки в регуляції ритму серця самців та викликає розвиток брадикардії. у самиць світлова депривація сприяє підтриманню балансу між активністю симпатичної та парасимпатичної ланок в умовах адреналін-індукованого некрозу міокарда, на відміну від самиць, що перебували в умовах зміни циклу день/ніч і демонстрували посилення активності симпатичної ланки АНС при розвитку некрозу міокарда.

КЛЮЧОВІ СЛОВА: некроз міокарда; варіабельність серцевого ритму; світлова депривація, стать

\section{Відомості про авторів}

Безкоровайна Галина Олександрівна - лікар, здобувач кафедри патологічної фізіології Тернопільського національного медичного університету імені І.я Горбачевського.

Кліщ Іван Миколайович - доктор біологічних наук, професор кафедри функціональної і лабораторної діагностики Тернопільського національного медичного університету імені І.Я Горбачевського.

Хара Марія Романівна - доктор медичних наук, професор кафедри патологічної фізіології Тернопільського національного медичного університету імені І.Я Горбачевськогою

Пелих Володимир Євгенович - кандидат медичних наук, доцент кафедри патологічної фізіології Тернопільського національного медичного університету імені І.Я Горбачевськогою

\section{Information about the authors}

Bezkorovaina H.O. - MD, Ph.D. Student, I. Horbachevsky Ternopil National Medical University, Ternopil, Ukraine. e-mail: 111ya111@ukr.net.

Klishch I.M. - MD, Ph.D., DSc, Professor, Functional and Clinical diagnostics Department, I. Horbachevsky Ternopil National Medical University, Ternopil, Ukraine.

ORCID 0000-0001-6226-4296, e-mail: klishch@tdmu.edu.ua.

Khara M.R. - MD, Ph.D., DSc, Professor, Pathophysiology Department, I. Horbachevsky Ternopil National Medical University, Ternopil, Ukraine.

ORCID 0000-0002-6028-9876, e-mail: khara@tdmu.edu.ua

Pelykh V.Ye. - MD, PhD, Associate Professor of Pathophysiology Department, I. Horbachevsky Ternopil National Medical University, Ternopil, Ukraine.

ORCID 0000-0003-3468-858X, e-mail: pelykh_ve@tdmu.edu.ua

\section{References}

1. Townsend N, Wilson L, Bhatnagar P, Wickramasinghe K, Rayner M, Nichols M. Cardiovascular disease in Europe: epidemiological update 2016. European Heart Journal. 2016 Aug 14;37(42):3232-45.

2. Roth GA, Forouzanfar MH, Moran AE, Barber R, Nguyen G, Feigin VL, Naghavi M, Mensah GA, Murray CJ. Demographic and epidemiologic drivers of global cardiovascular mortality. New England Journal of Medicine. 2015 Apr 2;372(14):1333-41. doi: 10.1056/NEJMoa1406656

3. EUGenMed, Cardiovascular Clinical Study Group, Regitz-Zagrosek V, Oertelt-Prigione S, Prescott E, Franconi F, Gerdts E, Foryst-Ludwig A, Maas AH, Kautzky-Willer A, Knappe-Wegner D. 
Gender in cardiovascular diseases: impact on clinical manifestations, management, and outcomes. European Heart Journal. 2015 Nov 3;37(1):24-34.

doi: 10.1093/eurheartj/ehv598

4. Pyle WG, Martino TA. Circadian rhythms influence cardiovascular disease differently in males and females: role of sex and gender. Current Opinion in Physiology. 2018 Oct 1;5:30-7.

doi:10.1016/j.cophys.2018.05.003

5. Reitz CJ, Martino TA. Disruption of circadian rhythms and sleep on critical illness and the impact on cardiovascular events. Current pharmaceutical design. 2015 Jul 1;21(24):3505-11.

6. Ariznavarreta $C$, Cardinali DP, Villanúa MA, Granados B, Martín M, Chiesa JJ, Golombek DA, and Tresguerres JA. Circadian rhythms in airline pilots submitted to long-haul transmeridian flights. Aviation, Space, and Environmental Medicine. 2002;73(5): 445-455. PMID: 12014603

7. Wulff K, Dijk DJ, Middleton B, Foster RG. Sleep and circadian rhythm disruption in schizophrenia. British Journal of Psychiatry.2012;200(4):308-16.

doi: 10.1192/bjp.bp.111.096321

8. Molcan L, Sutovska H, Okuliarova M, Senko T, Krskova L, Zeman M. Dim light at night attenuates circadian rhythms in the cardiovascular system and suppresses melatonin in rats. Life Sci. 2019;231:116568. doi: 10.1016/j.Ifs.2019.116568

9. Pandi-Perumal SR, Srinivasan V, Maestroni GJM, Cardinali DP, Poeggeler B, Hardeland R. Melatonin. Nature's most versatile biological signal? FEBS Journal. 2006;273(13):2813-38.

10. Gunn PJ, Middleton B, DaviesSK, Revell VL, Skene DJ. Sex differences in the circadian profiles of melatonin and cortisol in plasma and urine matrices under constant routine conditions. Chronobiol. Int. 2016;33(1):39-50.

doi: $10.3109 / 07420528.2015 .1112396$

11. Khara MR, Shkumbatiuk OV. Sex aspects of melatonin involvement in the regulation of heart rhythm in adrenaline damage. Clinical and Experimental Pathology. 2013; 46(4):126-129. [in Ukrainian]

12. Lin WL, Chen HR, Lo LW, Lai CT, Yamada $S$, Liu SH, Chou YH, Chen SA, Fu YC, Kuo TB. Sleeprelated changes in cardiovascular autonomic regulation in left coronary artery ligation rats: Neural mechanism facilitating arrhythmia after myocardial infarction. International Journal of Cardiology. 2016 Dec 15;225:65-72.

doi: 10.1016/j.ijcard.2016.09.121

13. Khara MR, Shkumbatiuk OV. Sex differences in metabolic changes in the myocardium in the development of a necrotic process against melatonin.
Actual problems of transport medicine. 2014;36(2, p-II):47-52. [in Ukrainian]

14. Kolettis TM, Kontonika M, Lekkas P, Vlahos AP, Baltogiannis GG, Gatzoulis KA, Chrousos GP. Autonomic responses during acute myocardial infarction in the rat model: implications for arrhythmogenesis. J Basic Clin Physiol Pharmacol. 2018;29(4):339-45.

doi: 10.1515/jbcpp-2017-0202

15. Baevsky RM., Ivanov GG., Chireikin LV. Analysis of heart rhythm variability when using various electrocardiographic systems (guidelines) // Bulletin of Arrhythmology. 2001;24:65-87. [in Russian].

16. Buoy MZ, Taratukhin EO. Possibilities of the method of heart rhythm variability. Russian Journal of Cardiology. 2011;6(92):69-75. [in Russian]

17. Thandroyen FT, Opie LH. Catecholamineinduced myocardial cell damage: Catecholamines or adrenochrome. J Mol Cell Cardiol. 1985;17(4):349-359.

18. Ahmed SS, Strobel HW, Napoli KL, Grevel J. Adrenochrome reaction implicates oxygen radicals in metabolism of cyclosporine A and FK-506 in rat and human liver microsomes. J Pharmacol Experim Therap. 1993;265(3):1047-54.

19. Khara MR, Bodnar YaYa, Fayfura VV. Features of structural changes in the heart of animals of different sex in the modelling of adrenaline myocardiodystrophy // Rus Morphol Statements. 2000;1(2):289290. [in Ukrainian]

20. Khara MR. Influence of trasicor on cholinergic reactions of heart of animals of different sex with adrenaline myocardiodystrophy. Galician Medical Bulletin. 2004;11(1):110-2. [in Ukrainian]

21. Khara MR. The modulating effect of carbacholin and castration on the cholinergic regulation of cardiac rhythm different sex rats in conditions of adrenaline myocardial damage. Bull Ukrain Dent Acad. 2003;3(2):13-5. [in Ukrainian]

22. Anishchenko TG, Igosheva IB. Sex differences of stress reactivity in awake and anesthetized rats under surgical stress. Bull Experim Biol Med. 1992; 113(1):26-8. [in Russian]

23. Talaei SA, Sheibani V, Salami M. Light deprivation improves melatonin related suppression of hippocampal plasticity. Hippocampus. 2010;20(3): 447-55.

doi: 10.1002/hipo. 20650

24. Cain SW, Dennison CF, Zeitzer JM, Guzik AM, Khalsa SB, Santhi N, Schoen MW, Czeisler CA, DuffyJF. Sex differences in phase angle of entrainment and melatonin amplitude in humans. J Biol Rhythms. 2010;25(4):288-96.

doi: $10.1177 / 0748730410374943$

Received 05 September 2019; revised 13 October 2019; accepted 23 October 2019.

This is open access article distributed under the Creative Commons Attribution License, which permits unrestricted use, distribution, and reproduction in any medium, provided the original work is properly cited. 